1975

\title{
Oxygen Uptake and Transport in the Lamellibranch Mollusc Modiolus demissus
}

Charles Edward Booth

College of William \& Mary - Arts \& Sciences

Follow this and additional works at: https://scholarworks.wm.edu/etd

Part of the Physiology Commons

\section{Recommended Citation}

Booth, Charles Edward, "Oxygen Uptake and Transport in the Lamellibranch Mollusc Modiolus demissus" (1975). Dissertations, Theses, and Masters Projects. Paper 1539624929.

https://dx.doi.org/doi:10.21220/s2-drcj-k017

This Thesis is brought to you for free and open access by the Theses, Dissertations, \& Master Projects at W\&M ScholarWorks. It has been accepted for inclusion in Dissertations, Theses, and Masters Projects by an authorized administrator of W\&M ScholarWorks. For more information, please contact scholarworks@wm.edu. 


\section{OXYGEN UPTAKE AND IRANSPORT IN THE IAMEILIBRANCH}

11

MOLLUSC MODIOLUS DEMISSUS

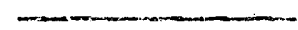

A Thesis

Presented to

The Faculty of the Departinent of Biology

The College of williain and Mary in Virginia

In Partial Fulfilmont

Of the Fequinements for the Degree of

Master of Arts

by:

Charles Eirard Booth

1976 
APPROVAL SHEET

This thesis is submitted in partial fulfillment of the requirements for the degree of

Master of Arts

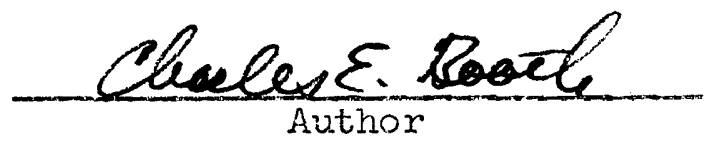

Approved, December 1976

Chaulosss A. Morgue
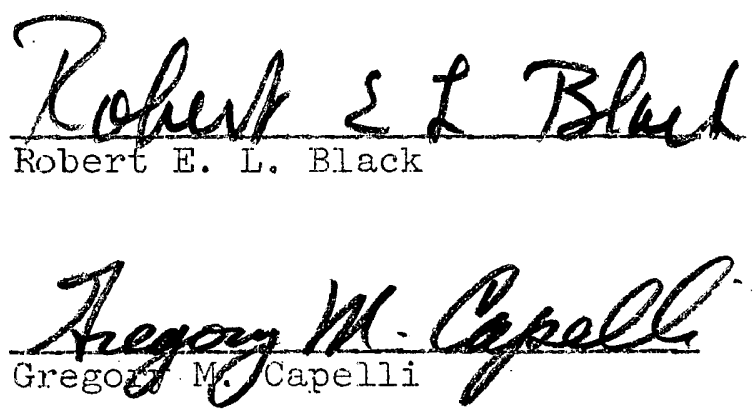

ii. 


\section{ACKNOWLEDGMENTS}

I would iike to express my sincere gratitude and appreciation to Dr. Charlotte P. Margum for her guidance and enthusiasm throughout the course of this study. I would also like to thank Drs. Robert E. L. Black and Gregory M. Capelli for their careful reading and criticism of the manuscript. I am also indebted to Mr. GIen Bean for his aid in the design and construction of equiptment, and to Lou Burnett for providing equiptment used in this stuòy. 
TABLE OF CONTENTS

page

ACKNOWLEDGMENTS . • . . . . . . . . . . . . . .

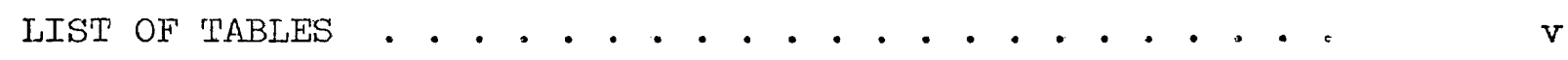

LIST OF FIGURES . . . . . . . . . . . . . . . . . . v vi v v v

ABSTRACT . . . . . . . . . . . . . . . . . . . vii INTRODUCTION . . . . . . . . . . . . . . . . . . 2

MATERTALS AND METHODS . . . . . . . . . . . . . . = 5

RESULIS . . . . . . . . . . . . . . . . . . . . 10

DISCUSSTON • . . . . . . . . . . . . . . . . . 29

SIJMMARY . . . . . . . . . . . . . . . . . 35

LITERATURE CITED . . . . . . . . . . . . . . . . . 36́

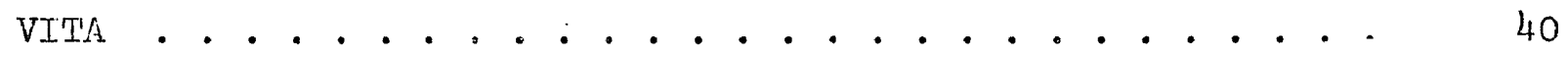




\section{LIST OF TABLES}

Table

1. The effects of ligation of the anterior aorta on

page cxygen consumption in Modiolus demissus, 210C, ambient $\mathrm{PO}_{2}=132-150$ torr. ..........

2. Blood oxygen levels in Modiolus demissus (mean \pm S.E.; number of ooservations indicatex in parentheses). . 23

3. Blcod and mantle cavity fluid pH in Modiolus demissus exposed to air (mean \pm S.E.), $22^{\circ} \mathrm{C} . . . \cdot . \cdot . \cdot . \quad 27$

4. Respiratory parameters of Modiolus demissus ard Noetia ponderosa, ambient $\widetilde{\mathrm{FO}_{2}}=140$ torr, $21-23^{\circ} \mathrm{C}$. 


\section{LIST OF FIGURES}

Fi.igure

1. Oxygen consumption by Modiolus demissus in water

page

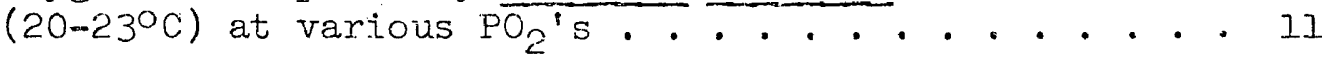

2. Per cent of oxygen extracted from the water $\left(20-23^{\circ} \mathrm{C}\right)$

by Modiolus demissus at vaxious ambient oxygen levels. I4

3. The effects of reduced ambient $\mathrm{PO}_{2}$ on heart rate ir

four submerged mussels $(20-230 \mathrm{C})$. . . . . . . 16

4. Heart rate in Modiolus demissus during air exposure

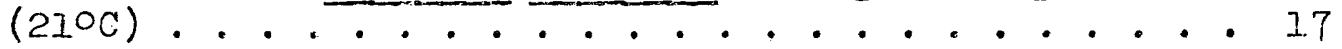

5. Ventilation rates of four mussels in declining ambient

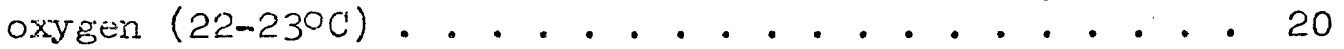

6. Major circulatory routes in Modiolus demissus showing blood $\mathrm{PO}_{2}$ 's at various points. . . . . . . . . 22

T. Blood $\mathrm{PO}_{2}$ in Modiolus demissus during anaerobiosis (210) . . ............... 26 


\section{ABSTRACT}

The mechanisms of oxygen uptake and transport are examined in Modiolus demissus, $\#$ lamellibranch mollusc with no specialized oxygen carrier in its blood. ModioIus, which has a high ventilatory rate and a iarge gill surrace area, equilibrates its blood with oxygen to a degree comparable to species with functional respiratory pigments. The high blood $\mathrm{PO}_{2}$ 's suggest that gas exchange occurs at several. superficial sites in addition to the gills. However, the small. reâction of $\mathrm{PO}_{2}$ in deep tissue indicates that, at high oxygen levels, the blood plays only a small role in oxygen transport. $\mathrm{vo}_{2}$ is $50 \%$ lower in air than in water, and during air exposure, there is almost complete equilibxation between the $\mathrm{PO}_{2}$ of water remaining in the mantle cavity and the blood. This relationship and the coservation that aerobic respiration generally ceases when the water $\mathrm{PO}_{2}$ falls to the jevels which occur in the mantle cavity, suggest that aerobic netabolism persists in superficial tissues by means of direct uptake of oxygen from the air, without participation of the blood. Deep tissue is believed to carry on primarily anaerobic metabolism during air exposure. 
OXYGEN UPTAIE AND TRANSPORT IN THE IAMELLIBRANCH MOLIUSC MODIOLUS DEMISSUS 


\section{INTRODUCTION}

While specialized oxygen carriers in the blood are found in several classes of molluscs, they have been lost within the class Lamellibranchia. In the lamellibranchs, hemoglobin is found circulating in the blood among members of the primitive taxodont families Arciciae and Glycymeridae, and it has a scattered occurrence in a few more advanced families. However, hemoglobin is absent from the vast majority of species. In the arcid clam Noetia ponderose, a minimurn of $90 \%$ of the oxygen carried by the blocd is bound to hemoglobin. In normoxic waters, the hemoglobin is fully oxygenated at the gill, and it delivers about 50\% of its locj to the tissues, which accounts for over haif of total oxygen uptare (Freadman and Nangurn, 1976; Deaton and Mangum, 1976). The reinaining portion of the oxygen consumed is carried in the plasma or is takon up by tissues directly from water.

The loss of hemoglobin, which reduces the oxygen carrying capam city of the blood by an order of magnitude, raises the question of the respiratory role of the blood. Previous studies of rolluscan respiration suggest that two adaptations mitigate the loss: I) Gill surface areas are larger (about $2 X$ ) and 2) Ventilation rates are much greater (10-15X) (Deaton and Mangum, 1.976). Rates of total oxygen consumption appear to be similar or even greater in several species without henoglobin. However, it is not clear that these adaptations are able to compensate fully in maintaining the respiratory role of 
the blood without a respiratory pigment. The only report of blood oxygen levels in the higher lamellibranchs was made by Taylor (1976b), who found high $\mathrm{PO}_{2}$ 's in the heart of Arctica islandica, which has no hemoglobin. No values were given for oxygen levels of the blood leaving delivery sites in this species. Even if 100\% of this oxygen were delivered to the tissues, a stroke volume of $5.23 \mathrm{mI}$ (at the measured heart rate of $7 \mathrm{bts} / \mathrm{min}$ ) would be required to account for the observed rates of oxygen consumption (Taylor and Brand, 1975a). Since an animal of $10 \mathrm{gm}$ dry body weight cannot have a stroke volume that approaches $5.23 \mathrm{ml}$, the blood must fuel only a small fraction of aerobic metaboitism.

This question of the respiratory role of blood is complicated. by several distinctive features of the lamellibranch circulatory system: 1) The blood is oxygenated in the mantle, as well as the gill. 2) Severai shunts allow blood to return to the heart without passing through the gill, and the blood may pass through several potential target organs before returning to a site of oxygen uptake. 3) The absence of extensive capillary networks suggests that the transport of oxygen to individual cells must be relatively inefficient. In addition, the partitioning of total oxygen uptake between direct (diffusion from water in superficial tissues) ard indirect (diffusion into blood and convection to deep tissues) paths to the tissues is not well known. Thus, there is an incomplete understanding of the respiratory mechanisms which have allowed the majority of lamellibranchs to attain such success with the seeming aisacivantage of no respiratory pigment.

In this study, the uptake and transport of oxygen have been exam- 
ined in the Atlantic ribbed mussel, Modiolus demissus demissus (Dillwyn) (Order Anisomaria.), which has no respiratory pigment in its. blood. Since $\mathbb{M}$. demissus inhabits the upper intertidal zone, its respiratory performance was studied in both water and air. 


\section{MATERIALS AND METHODS}

Mussels were collected from mudflats along the York River estuary (14-18 o/oo salinity) in Virginia, and maintained in air-saturated, recirculating natural water at room temperature $\left(20-23^{\circ} \mathrm{C}\right)$. OXYGEN CONSUMPITION

Mussels were kept in the laboratory for $2-3$ weeks prior to measurement of oxygen consumption. Each animal was first scrubbed to remove epiphytes, then placed in a respiratory vessel, and a polarographic oxygen electrode inserted in the top to seal it from the atmosphere. Air-saturated water at room temperature was siphoned. through the vessel long enough to allow ine mussel to open its valves and ventilate for 20-30 minutes. The siphon hoses were then clamped, stopping the water flow. The depletion of oxygen in the vessel was monitored with a YSI Model $54 \mathrm{O}_{2}$ meter and Model 50 laboratory recorder. The experiment was ended when the recorder trace showed no measureable oxyrgen uptake. The missel was then removed from its shell and dried at $60^{\circ} \mathrm{C}$ to a constant weight.

Oxygen consumption in air was measurea by placing mussels in custom-made pyrex vessels adapted for a Warburg constant volume respirometer. The vessels were incubated in a vater bath at $25^{\circ} \mathrm{C}$ for at least one hour, or until the mussels opened their valves to airgape. Oxygen uptake was then measured over a period of 3-4 hours. To estimate the role of the blood in respiration, oxygen consump- 
tion rates were also determined before and after ligation of the arterm ior aorta. One valve was removed and a threaci placed lcosely around the aorta. The mussel was then placed in Millipore-filtered water to which streptomycin $(0.1 \%)$ and penicillin $(0.1 \%)$ had been added to prevent bacterial growth. Oxygen consumption was rirst measured for 30 minutes and then the ligature tied off and the measurement repeated. To verify that circulation was blocked by the ligature, a solution of Prussian blue was injected into the hearts of mussels treated in this way. Although the heart continued. to contract, the dye did not flow into other regions of the circulatory system. OXYGEN EXTRACTION

The $\mathrm{PO}_{2}$ of the exhalant water current was measured with a hypodermic microelectrode (Beckman ), whose signal was amplified by a Bockman Model 160 physiological gas analyzer and recorded on a Iinear Instr. Corp. Model 112 pen recorder. The microelectrode was lowered with a micromanipulator into the exhalant siphon of mussels burrowed in sand. The $\mathrm{PO}_{2}$ of the inhalant current was measured with a polarographic oxygen electrode placed near the animal. The ambient $\mathrm{PO}_{2}$ was gradually lowered in 6-8 steps at intervals of about 30 minutes by bubbling nitrogen gas through the water. Musseis were allowed to ventilate for 10-15 minutes at each new $\mathrm{PO}_{2}$ before measurements were made. Results were computed by estimating the area under a continuous trace of $\mathrm{PO}_{2}$ as a function of time (Mangum and Burnett, 1975 ).

HEART RATE

Platinum pin electrodes were inserted into holes drilled through each valve on either side of the heart, and heid in place with dental 
wax (Surgident). Heart rates were recorded with an impedance pneumograph and multi-channel pen recorder (E. and M. Instr. Co.). The oxygen level in the water was gradually reduced over a period of 2-3 hours by introducing nitrogen gas .

Heart reies were also recorded in mussels exposed to air. A Jow tide was simulated by siowly $(1.5 \mathrm{hr}$ ) siphoning the water from an aquarium containing a mussel burrowed in sand. The mussels were exposed for periods of up to 4.5 hours, after which the water level was slowly (1.5 hr) raised and heart rates monitored for about one hour after full reimmersion. VENTITATTON RATE

Water flow rates from the exhalart siphon of submerged mussels were measured with a thermister flowmeter (Labarbera and Vogel, 1976) and recorded on a Iinear Instr. Corp. Model II2 pen recorder. Voltage to heat the thermister bead was provided by a Staco Incomp. ModeI \$8000 power source. The flowmeter, which senses only current velocity, vas calibratea to measure now rate by pumping water at various rates (determined with a volumetric flowmeter; Fmerson Electric Co.) through a tube whose shape and size approximated the mussel's exhalant aperture, past the probe tip. Calibration was performed before and after each experiment and corrections were made for any changes in the probe's response. The ambient $\mathrm{PO}_{2}$ was gradually lowered in $3-4$ steps over a period of 2 hours by introdicing nitrogen gas. Ventilation rates were recoided for $4-5$ minutes at each $\mathrm{PO}_{2}$. GIII SURFACE AREA

Gill dimensions were determined by removing a gill. and positioning it on filter paper in its natural shape and tracing its out- 
Iine. The dimensions of individual filaments of a submerged giIl. were measured under a compound microscope fitted with an ocular micrometer. The gills and remaining body tissue were then dried separately at $60^{\circ} \mathrm{C}$ to a constant weight.

\section{BLOOD VOLUME}

Blood volume was assumed to be equal to the difference in weight between cell water ard total water content of the animal. The total wet weight (blood and wet tissue) was measured after prying open the valves to drain the mantle cavity and removing the animal from its shell. After slashing the tissues and allowing the blood to drain for one hour, the tissue was blotted and wet tissue weight obtained. The tissue and blood were then dried separately at $60^{\circ} \mathrm{C}$ to a constant weight. The cell water content was determined to be the differerce betwen the wet and ary tissue weights. The total water content of the animal was calculated as the difference between total wet weight and the dry weight of the tissue and blood.

BLCOD OXYGEN CARRYING CAPACITY, POO

The oxygen carrying capacity of the blood was determined with a Lexington Instr. Corp. blood oxygen analyzer (LEX $\mathrm{O}_{2}$ CON-TI).

Blood samples were obtained anaerobically from various locations in the animal using a $1 \mathrm{ml}$ glass syringe and 25 gauge needle. Approximately $150 \mathrm{ml}$ of blood could be obtairied from the heart, while much larger volumes $(300-700 \mu \mathrm{l})$ were taken from the posterior adductor muscle and mesosomal sinus. Paired samples were taken from two locations within 20 seconds after removing a mussel from the water. Blood $\mathrm{PO}_{2}$ was measured by injecting samples into a Radiometer Corp. 
BMSl blood gas analyzer. Since a blood with little protein may not layer properly in a liquid-junction electrode, blood $\mathrm{pH}$ was determined with a Fisher combination electrode (glass type) and Model 540 digital pH meter. 
RESULTS

The curve describing normalized $\mathrm{VO}_{2}$ as a function of ambient $\mathrm{FO}_{2}$ (Fig. 1) faj.ls within the range of responses predicted for Modiolus demissus by the quadratic polynomial model of Mangum and Van Wirkle (1973), indicating littie regulation of onygen uptake. Paired measurements on mussels after 2 and 5 weeks in the laboratory showed no discernible changes in this pattern, unlike the related species 1ytilus edulis (Bayne, 1971).

Modiolus demissus does not exhaust the available oxygen supply but stops consuriing oxygen from the water rather suddenly, at a $\mathrm{PO}_{2}$ betwen 15 and 45 torr. This response, which also differs from that in M. elulis, is correlatea with a higher enzyme activity in the direction of anaerobic pathways than aerobic pathways (Fiammen, 1969 ). Mytilus edulis, which has a lower capacity for anaerobic metabolism (Hammen, 3.969), does not stop oxygen uptake-while oxygen is sti.l present in the water (Bayne and Livingstone, 1.976).

Although $\mathrm{M}$. demissus usually closes its valves when oxygen consumption stops at low $\mathrm{PO}_{2}$, on several occasions they reopened and gaped widely with the mantle margin spread, as if ventilating. RegardIess, no measureable oxygen consumption was detected. Wijsman (1.975) noted a similar behavior in $\underline{M}$. edulis and attributed it to a periodic Plushing of $\mathrm{CO}_{2}$ produced when the acidic end-products of anaerobic metabolism djssolve the calcareous shell. 
Fig. 1. Oxygen consumption by Modiolus demissus in water $\left(20-23^{\circ} \mathrm{C}\right)$ at various $\mathrm{PO}_{2}$ 's. Initial $\mathrm{VO}_{2}\left(\mu \mathrm{O}_{2} / \mathrm{gm}-\mathrm{hr}\right)$ values at $\mathrm{h}_{1}$ gh $\mathrm{PO}_{2}$ were set equal to 1.0 and all subsequent values expressed. as fractions of 1.0. Points on the solid line represent the mean ( \pm S.P.) for seven nusseIs. Since oxygen uptaire ceases at a low, but variable $\mathrm{PO}_{2}$, points on the dashed line represert mean values for a smaller number of animals, indicated. in parentheses. 


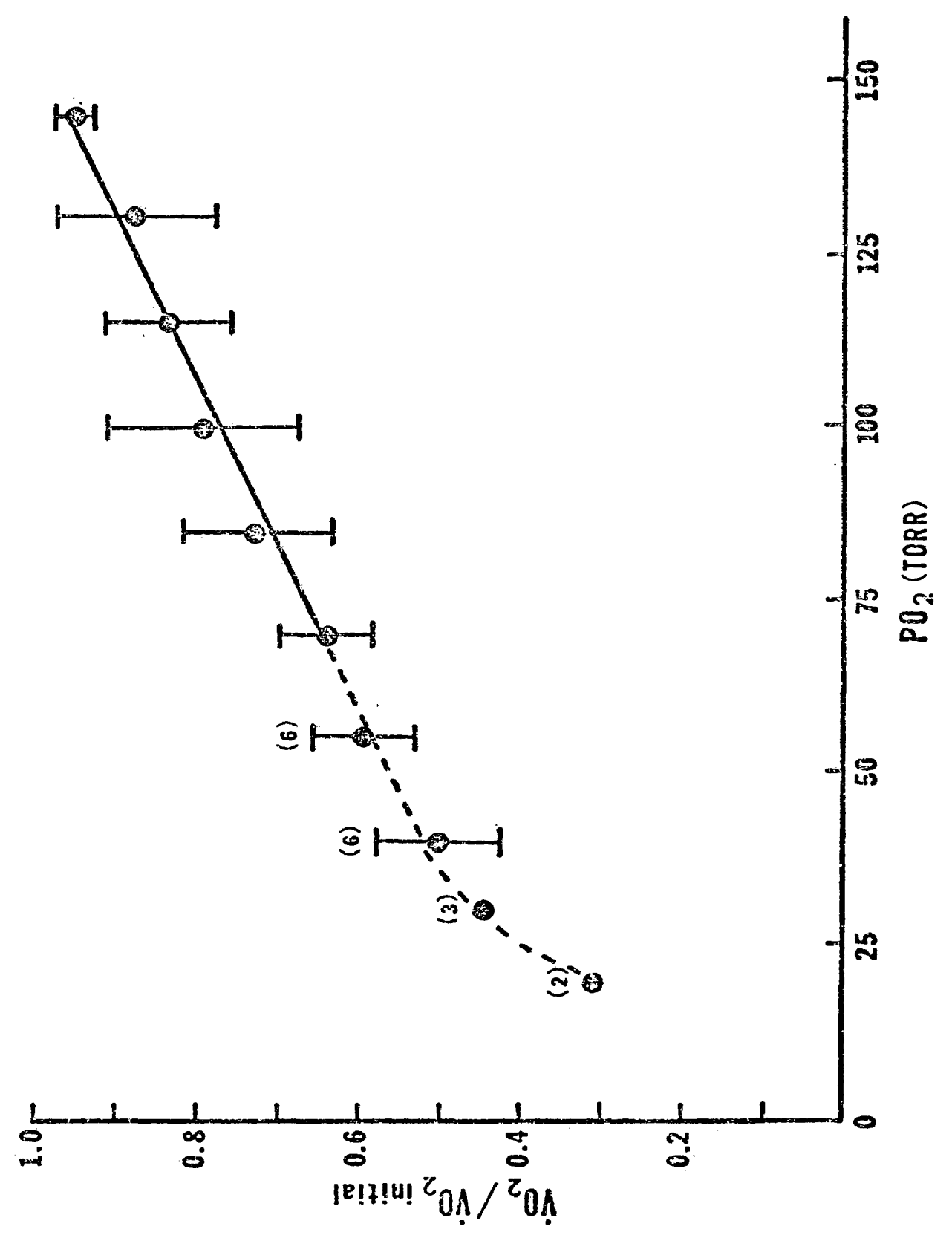


The mean $\mathrm{VO}_{2}$ (․․․․) for 7 mussels (mean dry weight $=.1 .35 \mathrm{gm}$ ) in water at a $\mathrm{FO}_{2}$ of 140 torr is $473 \pm 15 \mu \mathrm{I} \mathrm{O}_{2} / \mathrm{gm}-\mathrm{hr}(\mathrm{N}=14)$. In air, $\mathrm{VO}_{2}$ is more variable, reflecting the extent of shell gape; mean $\mathrm{VO}_{2}$ ( $\pm \mathrm{S} . \mathrm{E}$. ) for 6 mussels (mear ary weight $=2.43 \mathrm{gm}$ ) is $226 \pm 21$ ul $\mathrm{O}_{2} / \mathrm{gm}-\mathrm{hr}(\mathrm{N}=19)$. The lattex value is very close to that found under similar conditions by Kuenzler (1961). Using his estimates of the effect of body size on aerial $\mathrm{VO}_{2}$, the rate in a $1.35 \mathrm{gm}$ animal shoula be 232 ul $\mathrm{O}_{2} / \mathrm{gm}-\mathrm{hr}$. Thus, $\dot{\mathrm{VO}}_{2}$ in air is reduced to about $50 \%$ of that in water, which is a considerabiy larger decrease than found by Kuenzler ( 1961$)$. The ratio of aerial to aquatic $\mathrm{VO}_{2}(0.49)$ is also Low in comparison with Mytilus californianus $(0.738)$ and Cardium edule (0.655) (Bayne, et al, 1976b) and may be explained by the preferm ance for anaerobic metabolisin (Hammen, 1969). However, these results may even underestimate the difference; afuatic oxygen uptake was determined in November, when the gonads may te depleted of ganetes, and aerial oxygen uptake in $J u l y$, when they are ripe. If aerial $\dot{V}_{2}$ increases during gametogenesis, as does aquatic $\dot{V O}_{2}$ (Bayne, 1973), the ratio in M. demissus may be even lower.

The removal of one valve does not alter oxygen consumption rates; the rates are within the range found in intact animals. More importantly, ligation of the anterior aorta decreases oxygen uptake only by about 10-15\% (Table 1). OXYGEN EXTRACTIION

Oxygen extraction from the ventilatory current (Fig. 2) increases from $7-8 \%$ near air saturation to about. $35 \%$ at a $\mathrm{PO}_{2}$ of $25-30$ torr, a compensatory response which is also found in several other lamellibranchs (Mangum and Burnett, 1975; Taylor and Brand, 1975b). 
TABLE I

THE EFFECTS OF LIGATION OF THE ANTERIOR AORIA ON OXYGEN CONSUMPTION IN MODIOLUS DEMISSUS, $21^{\circ} \mathrm{C}$, AMBIENT $\mathrm{PO}_{2}=132-150$ TORR.

A. Paired measurements

Contro].

Mussel $\dot{\mathrm{VO}}_{2}\left(\mathrm{MI} \mathrm{O}_{2} / \mathrm{g}-\mathrm{hr}\right)$

$1 \quad 518.97$

$2 \quad 448.41$

$3 \quad 448.91$
Ligated $\dot{\mathrm{VO}}_{2}\left(\mu \mathrm{I} \mathrm{O}_{2} / \mathrm{g}-\mathrm{hr}\right) \quad$ \%Change 534.24 $+2.9 \%$ 398.59

$-11.1 \%$

356.49

$-20.6 \%$

B. Unpaired measurements ( 3 mussels unilgated, 3 musseis ligated)

Control

Mean $\dot{\mathrm{VO}}_{2}\left(\mu \mathrm{l} \mathrm{O}_{2} / \mathrm{g}-\mathrm{hr}\right.$

$444 \pm 3 I$ (S.E.) $(N=6)$
Ligated

Mean $\dot{\mathrm{VO}}_{2}\left(\mu \mathrm{O} \mathrm{O}_{2} / \mathrm{g}-\mathrm{hr}\right)$ \%Change

$377 \pm 43$ (S.E.) $(N=6) \quad-15.1 \%$ 
Tig. 2. Per cent of oxygen extracted from the water $\left(20-23^{\circ} \mathrm{C}\right)$ by Modjolus demissus at various ambient oxygen levels. Points on the solid line are the mean ( $t S . E$.$) for ten mussels, and$ those on the dashed line represent the mean ( \pm S.E.) for a. smaller number of animals (indicated in parentheses) in which oxygen uptake persisted at low $\mathrm{PO}_{2}$. 


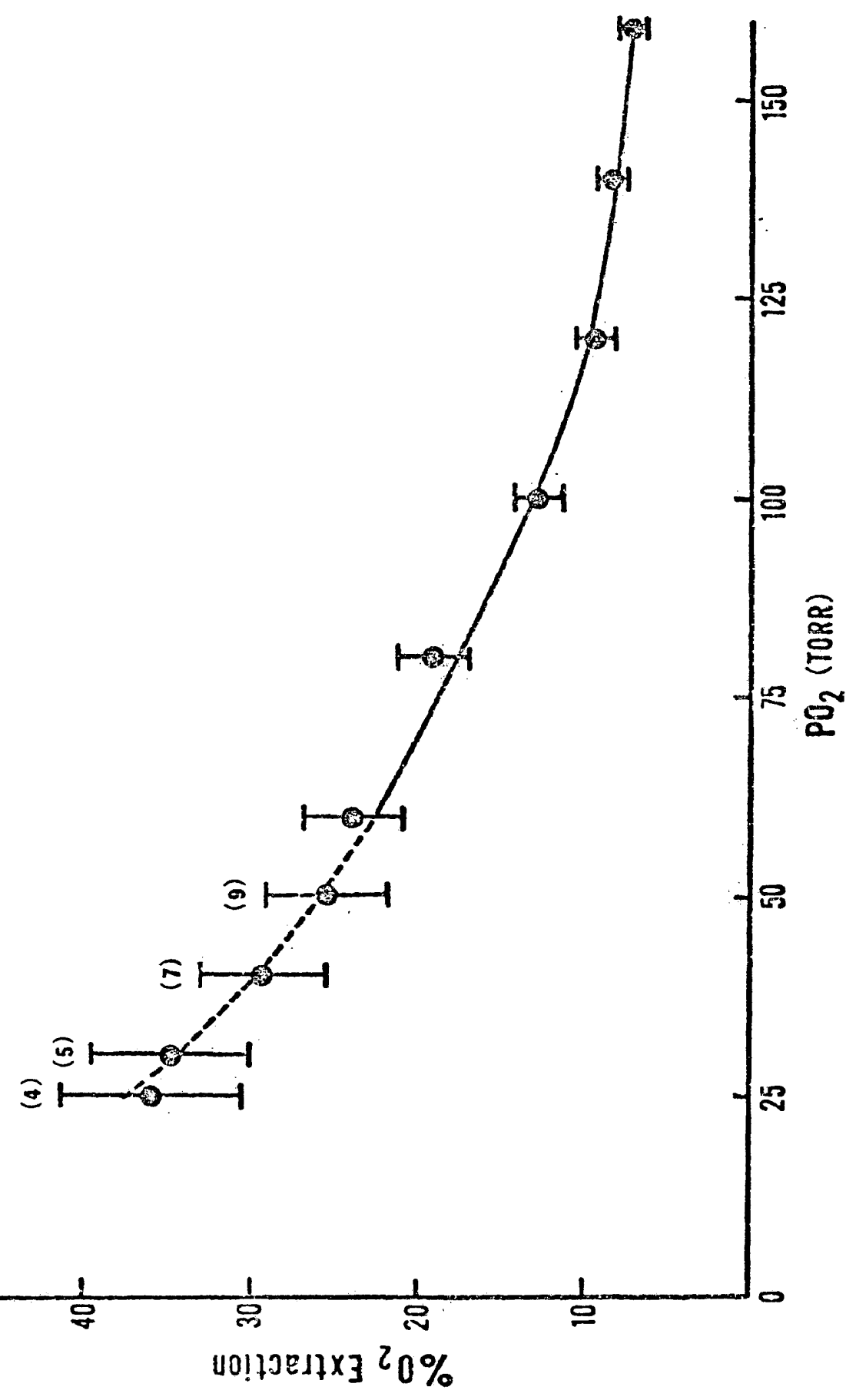




\section{HEART RAT'E}

At high $\mathrm{PO}_{2}$, heart rates generally ranged from $12-16 \mathrm{bt} / \mathrm{min}$, although baseline rates as low as $7 \mathrm{bt} / \mathrm{min}$ and as high as $17 \mathrm{bt} / \mathrm{min}$ were recordea. Since baseline rates were so variable even in a single animal, the values were normalized for presentation (Fig. 3). The most common response to declining oxygen is shown by mussels $A$, $B$, and $D$ (Fig. 3 ); an increase in rate $(2-4 \mathrm{bt} / \mathrm{min}$ or $12-22 \%)$ is followed by a sharp decrease at low $\mathrm{PO}_{2}$, immediately before valve closure. The heart rate in one animal (C) slowed graduajly until oxygen uptake ceased. Shortly after valve closure, heart rate drops to about 3-5 bt/min. The phenomenon of complete cardiac arrest found in Mytilus edulis (Bayne, 1971), never occurred in M. demissus, even after the valves had been closed for several hours. Otherwise, the tyoical response in $\mathbb{M}$. demissus resembles that in other lamellibranchs, eg. M. edulis (Bayne, 1971), Pecten maximus (Brand and Roberts, 1973), and Arctica islandica (Taylor and Brand, 1975b), despite the absence of aerobic shutdown in these species.

Exposure to air for periods of up to 4.5 hours caused no significant changes in heart rate in 5 sets of paired observations ( $P>0.05$; studentis t-test). A typical response, in which heart rate remains constant at $16 \mathrm{bt} / \mathrm{min}$ is shown in Fig. 4 ( $\mathrm{A}$ and $\mathrm{B}$ ). The persistence of circulation in $M$. demissus is strikingly different from the responses in several other air-gaping lamellibranchs. With two exceptions (Trueman and Lowe, 1971; Boyden, 1972), the intertidal and subtidal species studied previously show considerable bradycardia, or even complete suppression of heart rate, usually within cne hour after becoming exposed to air (Helm and Trueman, 1967; Coleman and 
Pig. 3. The effects of reduced ambient $\mathrm{PO}_{2}$ on heart rate in four submerged mussels $\left(20-23^{\circ} \mathrm{C}\right)$. Initial heart rates (beats per minute) at high $\mathrm{PO}_{2}$ expressed as $\mathrm{J.0}$, and all subsequent heart rates as fractions of 1.0 . 


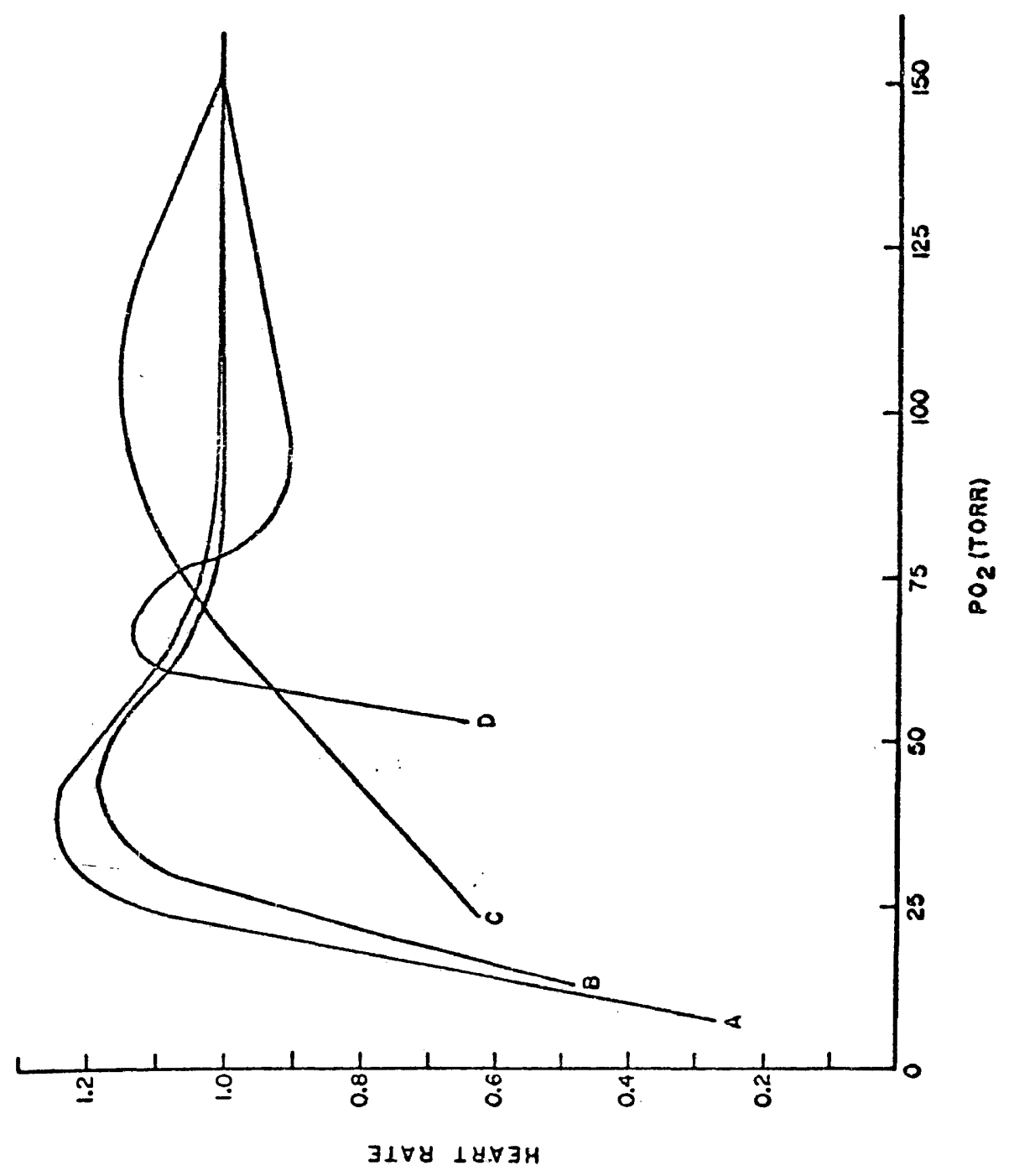


Fig. 4. Heart rate in Modiolus demissus during air exposure $\left(21^{\circ} \mathrm{C}\right)$. $\mathrm{A}=16 \mathrm{bt} / \mathrm{min}$, prior to exposure (water $\mathrm{PO}_{2}=150$ torr). $B=16 \mathrm{bt} / \mathrm{min}$, exposed to air for 70 minutes. $\mathrm{C}=18 \mathrm{bt} / \mathrm{min}$, immediately following reimnersion (water $\mathrm{PO}_{2}=150$ torr $)$. 


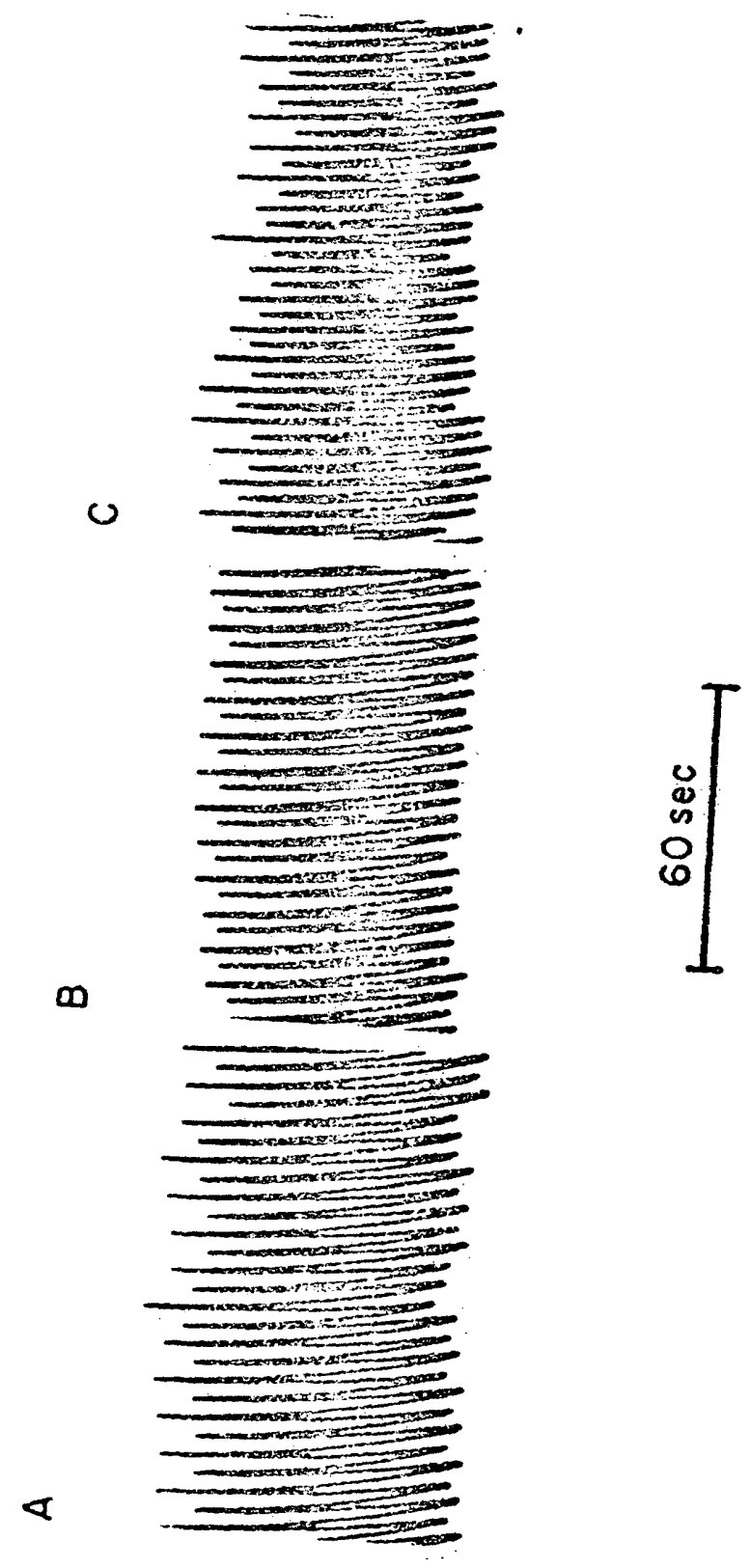


Irueman, 1971; Coleman, 1973; Brand and Roberts, 1973; Coleman, 1976; Bayne, et al, $1976 \mathrm{~b}$ ).

The capacity of lamellibranchs to buffer organic acids produced during anaerobic metabolism in air would be increased by release of the $\mathrm{CO}_{2}$ formed when the shell is dissolved; therefore, de Zwaan and Wijsman (1976) propose that air-gaping may serve to eliminate $\mathrm{CO}_{2}$ rather than to maintain aerobic metabolism. In $M$. demissus, the release of excess $\mathrm{CO}_{2}$ from the blood may be enhanced by the maintenance of a norral heart rate during air exposure. The advantage of eliminating $\mathrm{CO}_{2}$ must be balanced against the energetic cost of a relatively high heart rate. Thus, short bursts of cardiac activity observed periodically in several other air-gaping species (Coleman and Truerian, 1971; Brand and Roberts, 1973) may serve the same function, though perhaps less efficiently.

Upon reimmersion, heart rates in three of five mussels increased. bxiefly by $2-4 \mathrm{bt} / \mathrm{min}(15-25 \%)$, while tro showed no change. An exaraple of an increase in rate from 16 to $18 \mathrm{bt} / \mathrm{min}$ following air exposure is shown in Fig. 4C. In the cases of increase, the rates returned to control levels within one hour. This increase in circulation, which must entail increased energy expenditure, is a response which may explain the frequently observed "oxygen debt" phenomenon in species that do not oxidize the accumulated end-products of anaerobic metabolism (Mangum and Burnett, 1975). It may simply serve to flush anaerobically produced acids from the animal.

The amplitude of the heart beat as indicated by the deflection of the recording pen was quite variable, showing no correlation with heart rate. Therefore, an estimate of cardiac output from the product 
of heart rate and amplitude (Bayne, 1971; Taylor and Brand, 1975b) would be highly inaccurate, and thus was not attempted. VENTILATION RATTE

Ventilation rates in Modiolus demissus generally decrease at low $\mathrm{PO}_{2}$ 's (Fig. 5), and thus less oxygen is made available to the animal. The measured ventilation rates are sightly higher than those predicted from the Fick equation, using observed values of oxyger consurption and oxygen extraction. The small discrepancy is probably due to the procedure of volumetrically calibrating the flowmeter. A tube approximating the maximum dimensions of the exhalant siphon ves used, whereas the mussels continually change the shape of their exhalant aperture. Reductions in the size of the siphonal aperture could increase the exhalant current velocity without increasing the volumetric flow rate, which would result in the measured rates baing overestimated. QILI: SURFACE AREA

Jn 6 musels (1.15-3.8r gm dry weight), the dry weight of the gills comprises $8.2 \%$ ( $\pm 0.68 \mathrm{S.E.}$ ) of total dry body weight. The shape of a demibranch approximates a trapezoid measuring $5.20 \mathrm{X} 1.48 \mathrm{X}$ $3.20 \times 1.48 \mathrm{~cm}$ in a $20.15 \mathrm{gm}$ wet weight (1.35 gm dry veight) mussel. There are about 950 filaments and, in each lamella, a filament measures $0.0041 \mathrm{~cm}$ in width (frontal surface) and $0.0186 \mathrm{~cm}$ in depth (Iateral surface). The total surface area for gas exchange is approximately $13.9 \mathrm{~cm}^{2} / \mathrm{gm}$ animal wet weight, which is close to the value of $13.5 \mathrm{~cm}^{2} / \mathrm{gm}$ for Mytilus (Ghiretti, 1966). BLOOD VOLUME

The total water content in 10 mussels (mean wet weight $=20.4 \mathrm{gm}$ 
Fig. 5. Ventilation rates of four mussels in declining ambient oxygen $\left(2 ?-23^{\circ} \mathrm{C}\right) . t=$ indicates ventilation rate preaicted from experimental values for oxygen consumption and oxygen extraction. 


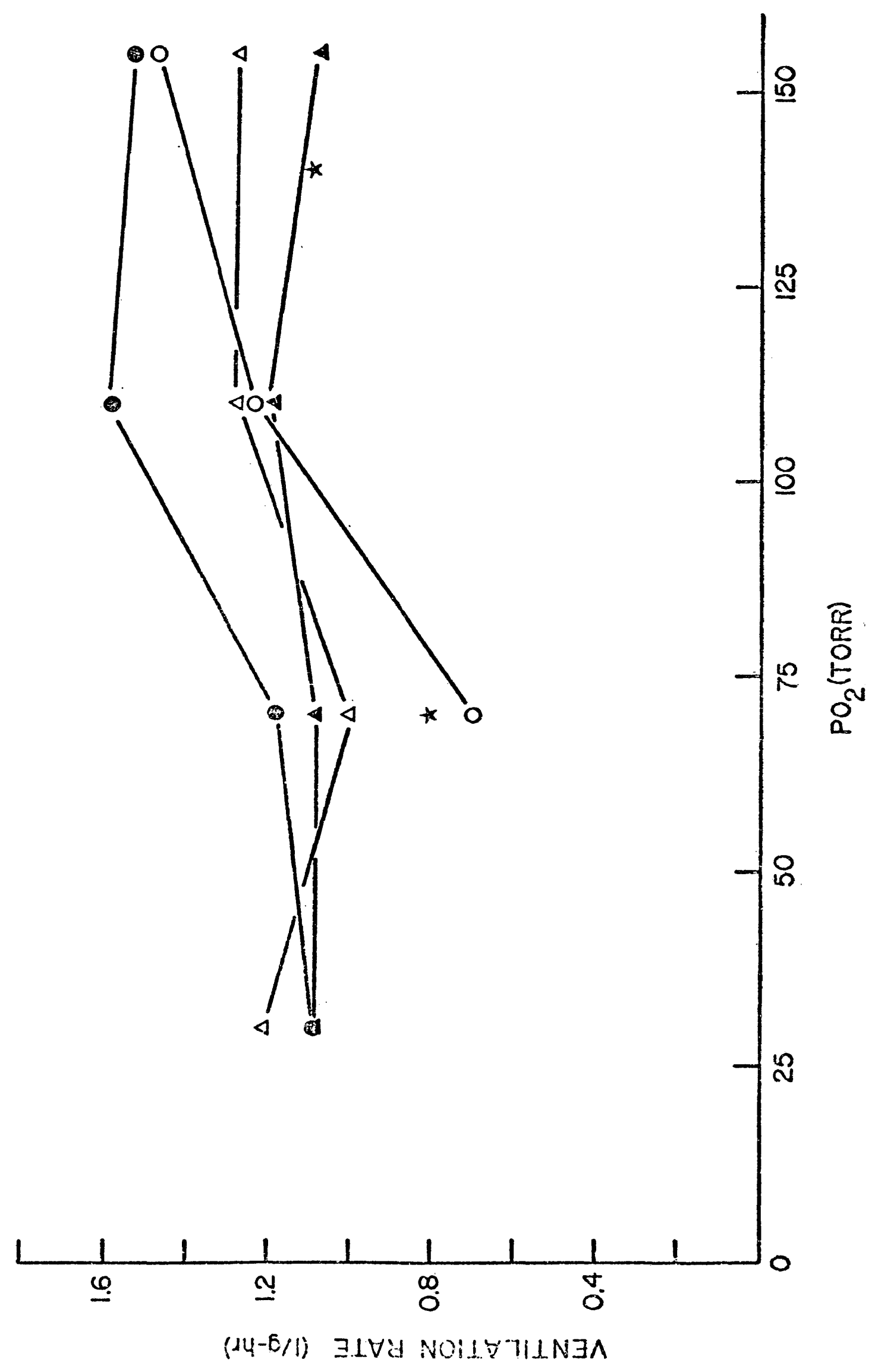


\pm 1.67 S.E. ) is $93.3 \%$ (t 3.52 S.E. ) of the total wet weight, or 19.03 gms. Blood accounts for $67.2 \%$ of the total water content. Thus, the blood volume is approximately $12.8 \mathrm{ml}$, or $62.7 \%$ of total. wet weight. This latter value is close to that for Noetia ponderosa (60.2\%; Deaton and Mangum, 1976), however, it is somewhat higher than the blood rolume of Nytilus californianus $(50.8 \%)$ and Margaritana margaritifera (49.0\%) (Martin, et al, 1958). BIOOD OXYGEN CARRYING CAPACITY, POQ

The oxygen concentration of blood equilibrated in vitro to the atmosphere $(0.6$ vols $\%)$ does not differ from that of water at the same saljnity and temperature. There is no evicience of a specialized oxygen carrier in the blood.

A generalized aiagram of the circulatory system in Modiolus. demissus, based on an account of mytilid anatony by White (1937) and persoral observations is shown in Fig. 6. From the longitudinal vein $(I, V)$, the heart receives both oxygenated blood from the gills (G) and deoxygenated blood from the viscera. (Vi). Therefore, mixing of the blood should result in a $\mathrm{PO}_{2}$ in the heart which is lower than that of blood leaving the gills. The efferent branchial vessel is too small to be sampled anaerobically; however, the extent to which the blcod can be oxygenated should be closely approximated by the highest $\mathrm{PO}_{2}^{\prime} \mathrm{s}$ observed, which are found in blood from the mesosomal sinus (Table $2 \mathrm{~A}$ ). Whe values found in the mesosomal and intermuscular sinuses (shown together as superficial sinuses, SS, in Fig. 6) are high and similar to one another, suggesting that these siruses are major sites of: oxygen uptake by the blood, along with the gill, and probably the mantle. Because oxygen uptake occurs at several sites with so much 
Fig. б. Major circulatory routes in Modiolus demissus showing blood $\mathrm{PO}_{2}$ 's at various points. $\mathrm{PM}=$ posterior adductor muscle, $\mathrm{AM}=$ anterior adductor muscle, $\mathrm{LV}=$ longitudinal vein, $\mathrm{SS}=$ superficjal sinuses (mesosoma and intermuscular sinuses), $\mathrm{K}=\mathrm{ki}$ dney, $\mathrm{Ve}=$ ventricle, $\mathrm{A}=$ auricle, $\mathrm{G}=\operatorname{gill}, \mathrm{Vi}=$ viscera, $F=$ foot, $M=$ mantle, $=$ oxygenated blood, $=$ deoxygenated blood, IIII $=$ mixed $\mathrm{blood}$. 


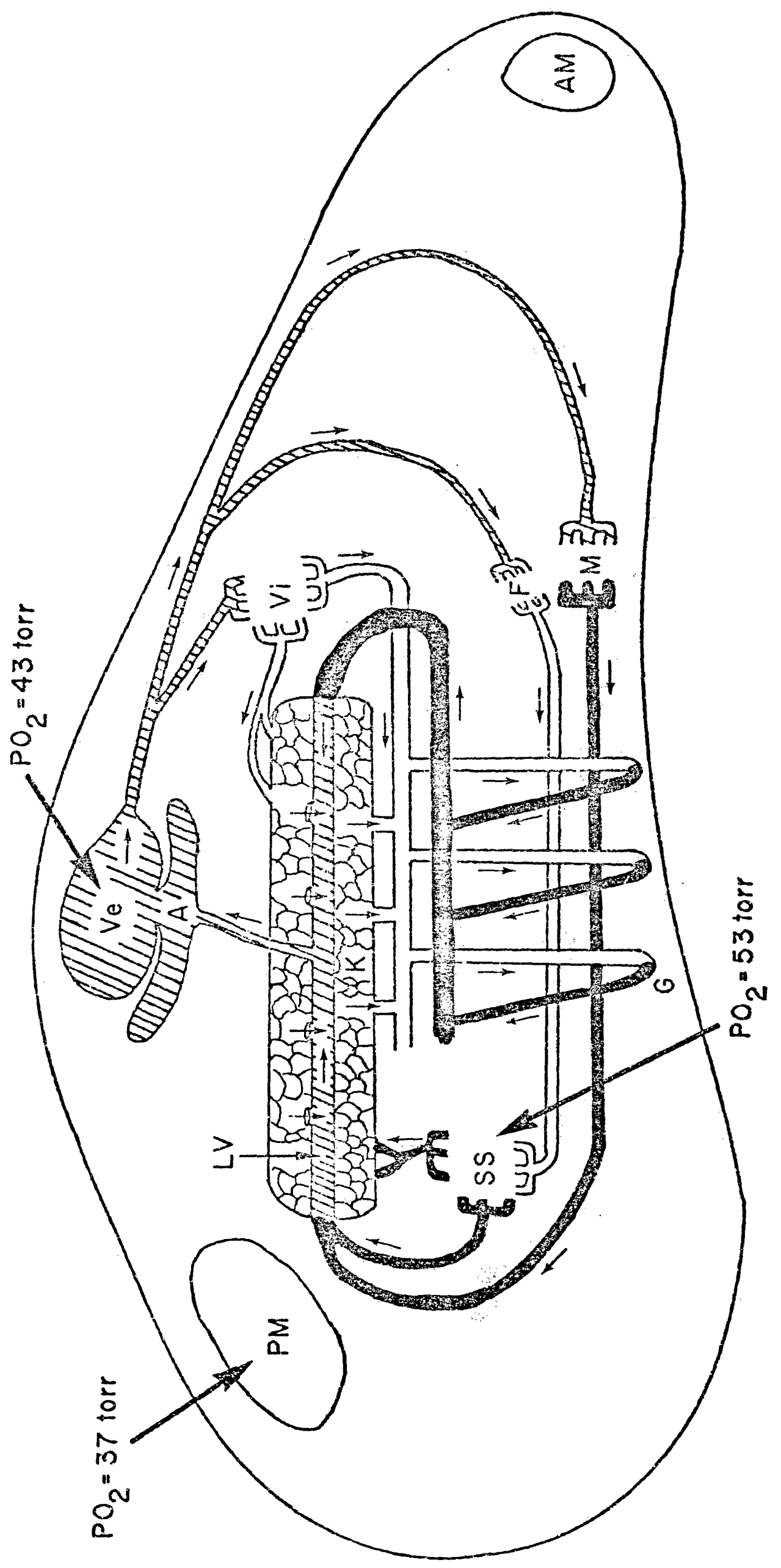




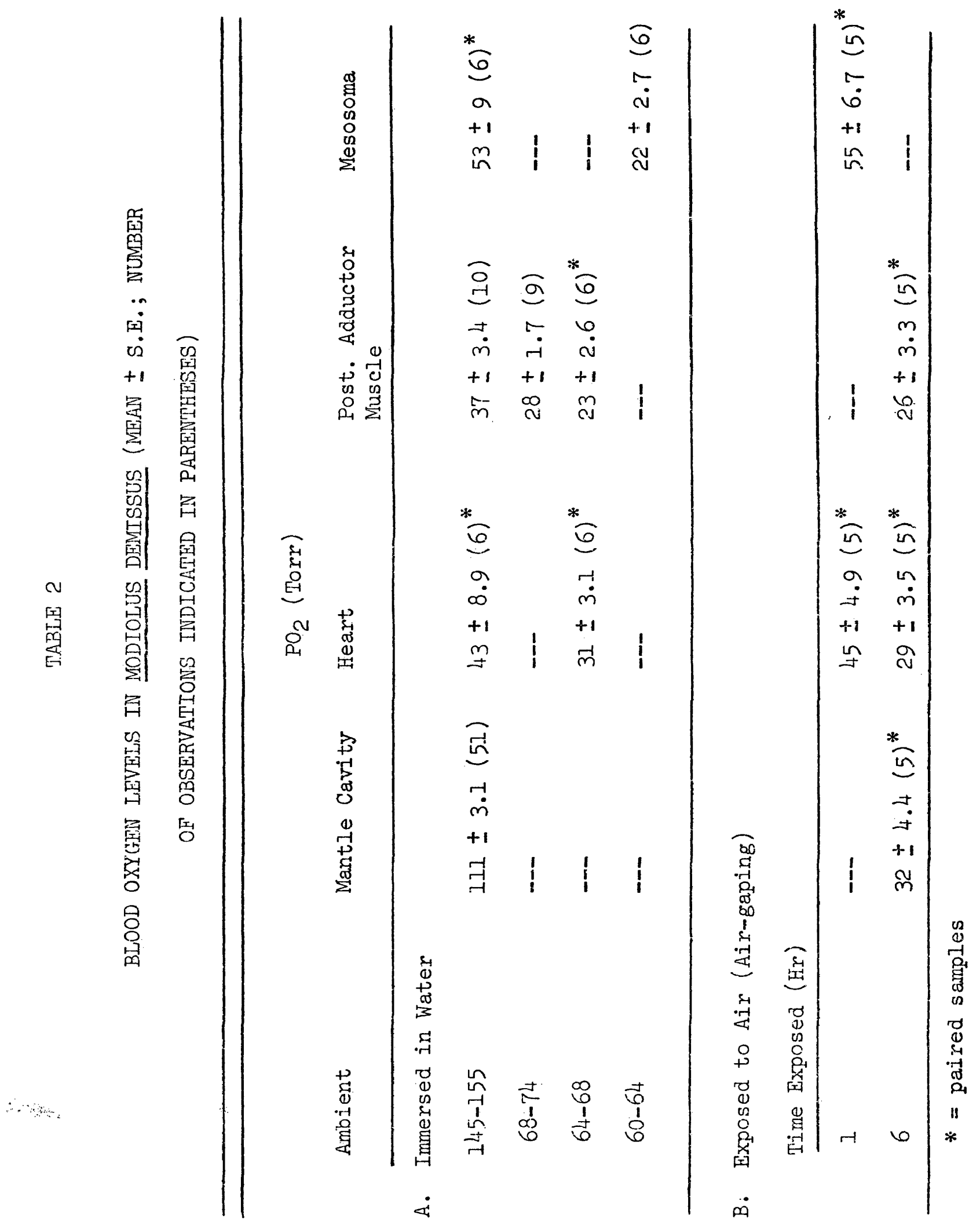


mixing of efferent and afferent blood, the conventional terins preand postbranchial do not reflect the oxygenation state of the blood. Both the mesosoma and intermuscular sinus appear externally as relatively thin-walled, blood-filled sacs along the ventral edge of the visceral mass, where they expose a large surface area to the inhalant current. The thickness of the niembrane separating water from the blood in the mesosoma is not known. However, the sinus is often highly inflated, distending the wall and thus decreasing the diffusion barrier. Although a relatively small diffusion distance separates the mesosomal blood from water, mesosomal blood also bathes the byssus retractor muscles and must deliver some of its oxygen to these tissues. Blood from the mesosoma empties into either the intermuscular sinus or the longituainal vein (White, 1937). The intermuscular sinus receives blood from the mesosoma and foot which ther empties into the kidney (White, 1937). Thus, the blood in the superricial sinuses is a mixture of oxygenated and deoxygenated blood. Yet, the $\mathrm{PO}_{2}$ of blood in the mesosoma ( 53 torr) is comparable to that in the heart of the hemoglobin-containing clams Noetia ponderosa $\left(\mathrm{PO}_{2}=62\right.$ torr; Freadman and Mangum, 1976) and Anadara ovalis $\left(\mathrm{PO}_{2}=\right.$ 55 torr; Mangum, 1973) at the same temperature. However, the $\mathrm{PO}_{2}$ of blood in a deep sinus, such as that in the posterior adductor muscle remains high (Table $2 \mathrm{~A}$ ), indicating a low rate of extraction of oxygen ( $14 \%$ ) from the blood.

When the water $\mathrm{PO}_{2}$ is Iowered to 60-68 torr, $\mathrm{PO}_{2}$ in the heart and posterior adductor muscle both drop (Table $2 \mathrm{~A}$ ), but the per cent extraction of oxygen from the blood almost doubles. At the same time, mesosomal $\mathrm{PO}_{2}$ is reduced to a value. slightly lower than that of 
the heart.

Air exposure for one hour has no effect on blood $\mathrm{PO}_{2}$ (Table $2 \mathrm{~B}$ ). However, within six hours, the values drop substantially. During this time, the $\mathrm{PO}_{2}$ of the mantle cavity fluid is reduced to about 32 torr. Paired samples show a $\mathrm{PO}_{2}$ difference of only 3 torr between mantle cavity fluid and the heart, and between the heart and posterior adductor muscle (Table $2 B$ ). Under these conditions, aerobic metabolism must be confined primarily to superficjal tissues in adequate contact with the air, while anaerobic metabolism must become nore important in deep tissues. This conclusion is supported by the substantial reduction in $V_{2}$ during air exposure (see above). Blood $\mathrm{PO}_{2}$ decreases in air exposed mussels whose valves have been tightly clamped. Mesosomal $\mathrm{PO}_{2}$ ( Fìg. 7) decreases sharply. over the first two hours, but does not arop below 11 torr, even after 3.5 hours of valve closure. A similar drop in $\mathrm{PO}_{2}$ occurs in blood from the posterior adductor muscle (Fig. 7). This result suggests that aerobic respiration continues immediately after valve closure utilizing oxygen from the blood, although it shuts down completely when blood $\mathrm{PO}_{2}$ reaches $10-15$ torr. Thaylor (1976a) found measureabie oxygen levels in the mantle cavity fluid and bicod of several incividuals of Arctica islandica which had been under anoxic conditions for five days. However, the $\mathrm{PO}_{2}$ of mantle cavity fluid in Mytilus californianus is reduced to zero. within one hour after valve closure (Moon and Pritchard, 1970).

After 24 hours without oxygen, which M. demissus easily tolerates (Lent, 1968), there is a pH drop of 0.48 both in blood from the posterior adductor muscle and in mantle cavity fluid (Table 3A), although 
Fig. 7. Blood $\mathrm{PO}_{2}$ ir Modiolus demissus during anaerobiosis $\left(21^{\circ} \mathrm{C}\right)$. - mesosoma, $O=$ posterior adäuctor muscle. 


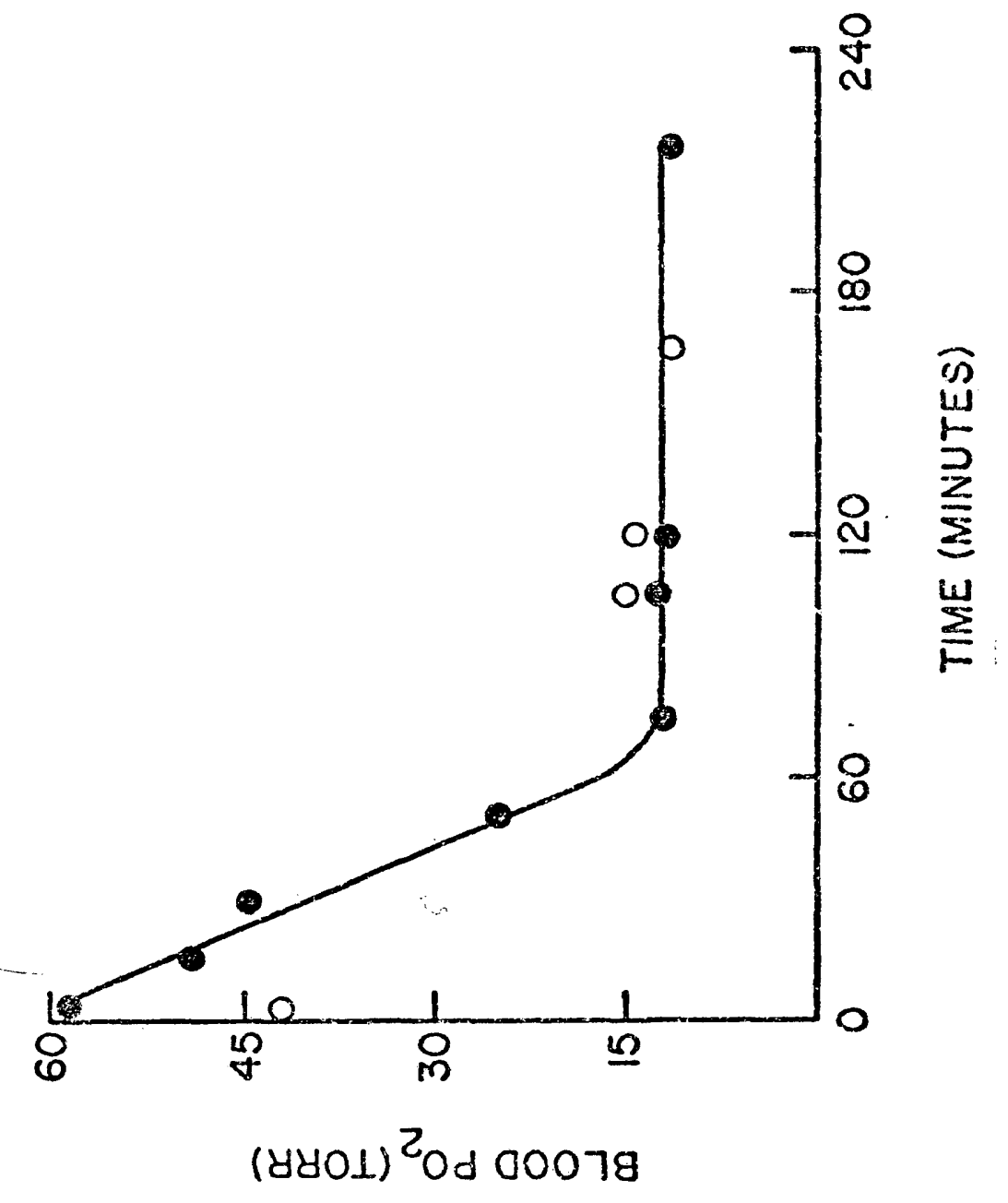


TABLE 3

BI,OOD AND MANTLE CAVITY F'LUID $\mathrm{pH}$ IN MODIOLUS DEMISSUS EXPOSED TO AIR (MEAN \pm S.E. ), $22^{\circ} \mathrm{C}$.

\begin{tabular}{|c|c|c|c|c|}
\hline & \multicolumn{4}{|c|}{ Time Exposed ( $\mathrm{Hr}$ ) } \\
\hline & & 0 & 6 & 24 \\
\hline \multirow[t]{3}{*}{ A. } & \multicolumn{4}{|c|}{ Anaerobiosis (valves clamped) $(N=4)$} \\
\hline & Post. Adauctor & $7.27 \pm 0.040$ & $7.09 \pm 0.176$ & $6.79 \pm 0.137$ \\
\hline & Mantle Cavity & $7.05 \pm 0.042$ & $6.82 \pm 0.1 .17$ & $6.57 \pm 0.167$ \\
\hline \multirow[t]{3}{*}{ B. } & Air-gaping $(N=4)$ & & & \\
\hline & Post. Adductor & $7.28 \pm 0.139$ & $-\infty$ & $7.02 \pm 0.028$ \\
\hline & Mantle Cavity & $6.72 \pm 0.070$ & -- & $6.74 \pm 0.043$ \\
\hline
\end{tabular}


the mantle cavity fluid is always more acid than the blood. Mytilus edulis shows changes in pH of $0.5-0.9$ during 24 hours of continuous valve closure (Wijsmari, 2975).

When N. demissus is allowed to air gape for 24 hours, blood piH drops only by 0.26 , while the $\mathrm{pH}$ of mantle cavity fluid does not change significantiy (Table $3 B$ ). This might be attributed to a Iower concentration of acid end-products from anerobic metabolism during air-garing, however, it is more likely a result of the release of $\mathrm{CO}_{2}$ produced when these acids are buffered by the shell (Wijsmar, 1975).

During periods of anaerobiosis, biood pH in $M$. demissus is above the pH optimum (6.5-6.6) for the enzyme phosphoenolpyruvate carboxykinase (de Zwaan ard de Bont, 1975), which directs the flow of carbon into anaerobic pathways. This suggests that aerobic pathways preaminate. However, the results of in vivo and in vitro studies axe contradictory; under hypoxic conditions, substances believed to be anaerobic end-products accumulate in the posterior adductor muscle of Mrtilus edulis (de Zwaan and Zandee, 1972; Livingstone and Bayne, 1976). Yet, Wijsman (1975) found that, even under anoxic conditions, submerged $M$. edulis maintains its $p H$ at $7.3-7.5$ by periodic flushing of the mantle cavity. In $\underline{M}$. demissus, the persistence of oxygen in the blood after several hours of valve closure suggests that anaerobic respiration predominates, despite the relatively high blood pH. 


\section{DISCUSSION}

While gas exchange across permeable body surfaces must occur to some degree in all aquatic molluscs, it is often overlooked. The large amounts of soft body tissue exposed to the ventilatory current suggest that the direct entry of oxygen into these tissues may account For a substantial fraction of total oxygen uptake in the lamellibranchs. In adition, the high mesosomal $\mathrm{PO}_{2}^{\prime} \mathrm{s}$ in Modiolus demissus inaicate that branchial and pallial oxygen uptake in the mytilid body type are further supplemented by the large superficial sinuses. Thus, the sites of gas exchange are far more numerous than portrayed previously, resulting in high blood $\mathrm{PO}_{2}$ 's which are in the range found in species with respiratory pigments.

However, the small decrease in $\dot{\mathrm{V}}_{2}$ after blocking circulation, and the very small reduction of blood $\mathrm{PO}_{2}$ in deep tissues when circuIation, is unimpaired, indicate that the blood plays a limited role in transporting oxygen. A greater delivery of oxygen to the tissues in the posterior adductor muscle has been found in Mytilus edulis (B. L. Bayne, personal communication). However, the present author has found that $\mathrm{PO}_{2}$ of blood from the adductor muscle is also high (40 torr) in Mya aremaria, suggesting that the results for $\underline{M}$. demissus are not atypical. In addition, lamellibranchs are very tolerant of blood loss, and the survival of Mytilus califormianus is unaffected for several weeks after most of its blood is withdrawn (C. J. Costa, personal communication). Thus, the respiratory function of the blood in these 
lamellibranchs must be small, and the circulating body fluids must be primarily involved in other physiological functions such as nutrition, salt and water balance, and excretion of metabolic wastes. This conclusion is supported by the unrealistic estimate obtained for blood flow by computations, assuming that blood is an important carrier of oxygen. For example, if 1). the blood transports $100 \%$ of the oxygen consumed, and 2) the highest (mesosoma) and lowest (posterior adductor) $\mathrm{PO}_{2}^{\prime}$ 's observed are actually representative of all sites of uptake and delivery, then the Fick equation predicts that cardiac output of a $1.35 \mathrm{gm}$ animal would be $17.7 \mathrm{ml} / \mathrm{min}$. At a heart rate of $14 \mathrm{bt} / \mathrm{min}$, stroke volume would be $1.26 \mathrm{ml}$, whereas the actual heart volume, estimated by syringe withdrawl and distension, is only 0.150-0.175 $\mathrm{ml}$. If, however, the blood carries only a small fraction (10-15\%) of the oxygen consumed, which vas inferred from the experimental blockage of circulation, stroke volume" would only be 0.126-0.189 ml.

Even though blood-borne oxygen accounts for a relatively small portion of total oxygen uptake, the blood may still be essential in transporting oxygen to specific tissues such as the adductor muscles, which comprise a small fraction of the total biomass. Nonetheless, it is possible that some deep tissues may always function anaerobicalIy, regardless of external oxygen levels. Mitochondria are not very abundant in adauctor muscle tissue (Mattisson and Beechey, 1966; Hochachka and Mustafa, 1973) and they may be relatively small compaired to those in more active muscles (Hanson and Lowy, 1961). Tappel (1960) found low concentrations of cytochromes in the adductors of several lamellibranchs. Likewise, Addink and Veenhof (1975) found high activities for glycolytic enzymes in the posterior adductor 
muscle of Mytilus edulis, suggesting that its primary source of energy is giycolysis. However, while the activity of anaerobic pathways in the adductor muscle may increase at low oxygen, the blood must supply aerobic pathways as well, as indicated by the continuation of oxygen removal from the blood at low ambient $\mathrm{PO}_{2}$. The increase in extraction of oxygen from the blood reflects a greater importance of blood under hypoxic conditions. However, the decrease in ventilation rate at lower $\mathrm{PO}_{2}$ 's is not offset by the small increase in the respiratory role of blood, and oxygen consumption is not maintained at a constant level.

When $\underline{M}$. demissus air-gapes, the virtual equilibration of $\mathrm{PO}_{2}$ 's in the mantle cavity fluid and the blood, and the small extraction of oxygen from the blood in the posterior adductor muscle suggest that the tissues consume very little oxygen from the blood. This is consistent with the results of Bayne, et al (1976b), who found an accumulation of anaerobic end-products in the adductor muscle of $\underline{M}$. californianus during air-gaping. In addition, Coleman (1973) found that siltting the posterior adductor muscle, which must result in blood loss, does not significantly alter oxygen consumption in $\underline{M}$. edulis during air-gaping. The major portion of oxygen consumed, thereiore, is probably extracted by the tissues directly from the mantle cavity water, or, when water is lost, from the air. If the low $\mathrm{PO}_{2}$ of the mantle cavity fluid is the limiting factor of oxygen uptake during air exposure, then $\dot{\mathrm{V}}_{2}$ may depend on the amount of water retained in the mantle cavity; a loss of water would expose a greater amount of tissue to the air. The resultant Jevel of aerobic metaboilism may be a compromise between the demands of energy produc- 
tion and resistance to dessication.

A comparison of respiratory parameters in Modiolus demissus. with those of the hemoglobin-containing species Noetia ponderosa, is presented in Table 4. Despite the high oxygen carrying capacity of its blood and the large difference between oxygen concentration of afferent and efferent blood, $\dot{\mathrm{VO}}_{2}$ in $\underline{\mathbb{N}}$. ponderosa is about $67 \%$ of that in M. demissus. Similarly, Krüger (1958) found that $\dot{\mathrm{VO}}_{2}$ in Glycymeris nummaria is greatest in individuals with the lowest hemoglobir concentrations. The loss of a pigment that increases oxygen extraction from the water is accompanied by an increase in ventilation rate. This increase can be brought about I) by enlarging gill surface area, and 2) by pumping harder, which must increase the metabolic demand. The larger gill surface area in $\underline{M}$. demissus (rable 4) is primarily due to the width of the lateral surface of the gill filaments $(0.0186 \mathrm{~cm})$ which is more than three times that in N. ponderosa $(0.0056 \mathrm{~cm}$; Deaton and Mangum, 1976). The dimensions of the frontal surface of the filaments are similar in the two species. Since the cilia responsible for the ventilatory current are located on the lateral surface of the filaments, the differences in ventilatory rate may be explained by the difference in gill surface area. However, since blood volume and heart rates in $\mathbb{N}$. ponderosa (I. ㄴ. Deator, unpublished data) and $\underline{M}$. demissus are similar, the higher oxygen concentration of efferent blood in $\mathbb{N}$. ponderosa suggests that the enlargement of gill surface area cannot compensate for a greatly reduced oxygen carrying capacity of the blood.

The evolution of high pumping rates in lamellibranchs is generalIy regarded as an adaptation more for filter-feeding than for gas 


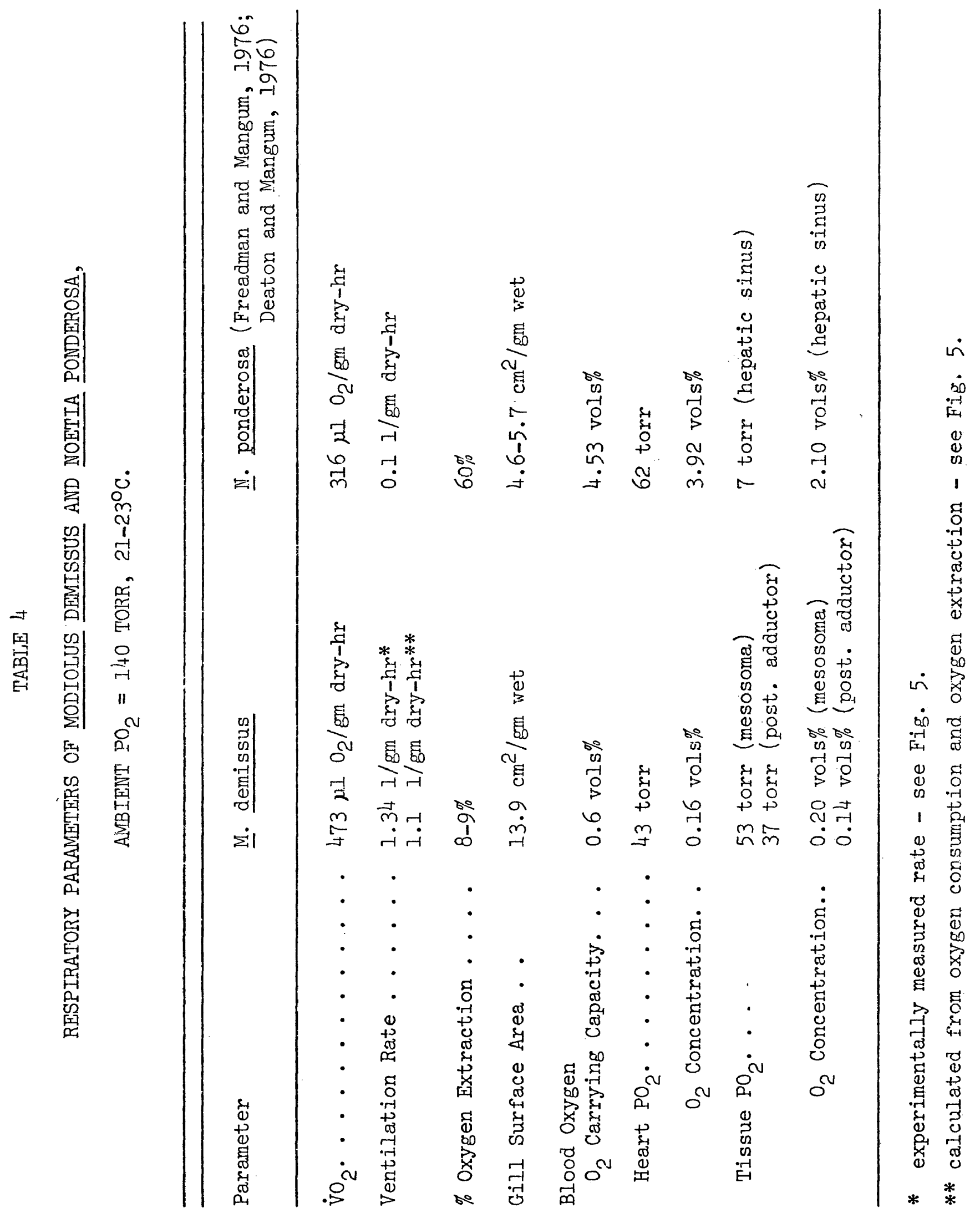


exchange, based on the low oxygen extraction efficiencies in most species. However, the ventilation rate in $\underline{M}$. demissus may be related to its rate of aerobic metabolism as well as its nutritional state. The measured per cent oxygen extraction is an average of oxygen removal at many superficial sites, in addition to the gill. Water passing through the mantle cavity may transport oxygen to remote body surfaces which extract it with a high efficiency, while oxygen extraction at the gill is low. If the ventilation rate is increased until the more remote tissue is adequately fueled, the average rate of oxygen extraction by all of the multiple sites might be low. Bayne, et al (1975a) have calculated that the mechanics of ventilation require $59 \%$ of the oxygen consumed in Mytilus californianus. Thus, the difference between $\mathrm{VO}_{2}$ in $\underline{M}$. demissus and $\underline{N}$. ponderosa might ie at least partially explained by a ventilation rate in M. demissus which is more than ten times that of $\mathrm{N}$. ponderosa. Regardless, it is apparent that the role of the blood in transporting oxygen differs greatly in species with a functional respiratory pigment and those with none. It seems that, in Modiolus demissus and some other members of the family Mytilidae, blood may become important only under conditions of low oxygen; at high ambient $\mathrm{PO}_{2}$, their metabolism does not involve the substantial participation of the circulatory system. This shift in the respiratory role of the blood is accompanied by an ability to supply superficial tissues vith oxygen derived from air, which, along with the capacity for facultative anaerobiosis in deep tissue, is a major factor in allowing the successful exploitation of the upper intertidal zone. 
SUMMARY

1. The blood of Modiolus demissus, which lacks a respiratory pigment, equilibrates with oxygen in the water to a degree comparable to species with blood pigments; however, only $14 \%$ of the oxygen is delivered to the tissues.

2. The high blood $\mathrm{PO}_{2}$ in the mesosoma suggests that this is an important site for blood gas exchange, along with the gill and mantle. 3. In highly oxygenated water, blocking the circulatory system depresses oxygen consumption rates by only $15 \%$, indicating that the primary route of oxygen uptake is direct, into superficial tissues. 4. At low ambient oxygen, there is an increase in heart rate and per cent oxygen extraction from the water; however, $\underline{M}$. demissus is a poor regulator of oxygen consumption.

5. When water $\mathrm{PO}_{2}$ falls below 40-50 torr, $\mathrm{M}$. demissus generally closes its valves and ceases to respire aerobically. 6. During air exposure, $\underline{M}$. demissus extracts oxygen from the air, although its rate of oxygen uptake is reduced by $50 \%$. At this time, the primary pathways of metabolism in deep tissue are probably anaerobic. 
LITERATURE CITED

Addink, A. D. F. and P. R. Veenhof. 1975. Regulation of mitochondrial matrix enzymes in Mytilus edulis L.. Pages 109-119 in $\mathrm{H}$. Barnes, ed. Proceedings of the Ninth European Niarine Biology Symposium. Aberdeen University Press.

Bayne, B. L. 1971. Ventilation, the heart beat and oxygen uptake by Mytilus edulis $\mathrm{L}$. in declining oxygen tension. Comparative Biochemistry and Physiology 40A: 1065-1085.

Bayne, B. L. 1973. Physiological changes in Mytilus edulis L. induced by temperature and nutritive stress. Journal of the Marine Biological Association of the United Kingdom 53: 39-58.

Bayne, B. I., C. J. Bayne, T. C. Carefoot, and R. J. Thompson. 1976a. The physiological ecology of Mytilus californianus Conrad. 1. Metabolism and energy balance. Oecologia (Berl.) $22:-211-228$.

Bayne, B. L., C. J. Bayne, T. C. Carefoot, and R. J. Thompson. 1976b. The physiological ecology of Mytilus californianus Conrad. 2. Adaptations to low oxygen tension and air exposure. Oecologia (Berl.) 22: 229-250.

Bayne, B. L. and D. R. Iivingstone. 1976. Responses of Mytilus edulis $I$. to low oxvgen tension: acclimation of the rate of oxygen consumption. Journal of Comparative Physiology (in press).

Boyden; C. R. 1972. The behavior, survival, and respiration of the cockles Cerastoderma edule and $\underline{C}$. glaucum in air. Journal of the Marine Biological Association of the United Kingdom 52: 661680 .

Brand, A. R. and.D. Roberts. 1973. The cardiac responses of the scallop pecten maximus (I.) to respiratory stress. Journal of Experimenta. Marine Biology and Ecology 13: 29-43.

Coleman, N. 1973. The oxygen consumpition of Mytilus edulis in air.

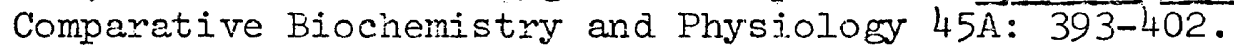

Coleman, N. 1976. The aerial respiration of Modiolus modiolus. Comparative Biochemistry and Physiology 54A: $401-406$.

Coleman, N. and $E$. R. Trueman. 1971. The effect of aerial exposure on the activity of the mussels Mytilus edulis L. and Modiolus 
modiolus (L.). Joumal of Experimental Marine Bjology and Icology $7: 295-403$.

Deaton, I. E. and C. P. Niangum. 1976. The function of hemoglobin in the arcid clam Noetia ponderosa-T. Oxygen uptake and storage. Comparative Eiochemistry and Physiology 53A: 181-186.

Freadinan, M. A. and C. P. Mangum. 1976. The function of hemogiobin in the arcia clam Noetia ponderosa-II. Oxygenation in vitro and in vivo. Comparative Biochemistry and Physiology $5 \overline{\mathrm{A}}$ : $173-179$.

Ghiretti, F. 1956. Respiration. Page 181 in K. M. Wilbur ard C. M. Yonge, eds. Physiology of the Mollusca. Vol. II. Acaderric, New York.

Hammen, C. S. 1969. Lactate and succinate oxidoreductases in marire inveriebrates. Marine Biology 4: 233-238.

Hanson, J. and $J$. Lowy. 1961. The structure of the muscle fibres in the transiucent part of the adductor of the oyster Crassostrea angulata. Froceedings of the Roya? Society B 154: 173-196.

Helm, M. M. and E. R. Trueman. 1967. The effect of exposure on the heart iate of the mussel, Mytilus edulis I.. Comparative Biochemistry and Physiology 21: 171-177.

Hochachka, P. W. and T. Mustafa. 1973. Enzymes in facultative anaerobiosis of molluscs-I. Malic enzyme of oyster adductor muscle. Comparative Biochemistry and Physiology 45B: 625-637.

Krüger, F. 1.958. Beiträge zur Physiologie des Hämoglobins wirbelioser Tiere. IV. Zur Atrungsphysiologie von Glycimeris nummaria (Linne) (Mol.Iusca: Lamsilibranchiata). Zoologjsche Janrbucher 67: 31]-322.

Kuenzier, E. J. 1961. Structure and energy flow of a mussel population in a Georgia salt marsh. Limnology and Oceanography 6: $19 ?-204$.

Ient, C. M. 1.968. Air-gaping by the ribbed mussel, Modiolus demissus (DiIJnyn): effects and adaptive significance. Biological BuIm letin 134: $60-73$.

Livingstone, D. R. and B. L. Bayne. 1976. Responses of Mytilus edulis L. to low oxygen tensions: anaerobic metabolism of the posterior adductor muscle and mantle tissue. Joumal of Comparative Physiology (in press).

Manguin, C. P. 1973. Evaluation of the functional properties of invertebrate hemoglobins. Netherlands Journal of Sea Research 7: $303-315$.

Mangum, C. P. and I. E. Burnett. 1975. The extraction of oxygen by estuarine invertebrates. Pages 147-163 in F. John Vernberg, ed. 
Physiological Ecology of Estuarine Organisms. University of South Caroiina Press, Columbia.

Mangum, C. P. and W. Van Winkle. 1973. Responses of aquatic invertebrates to declining oxygen conditions. American Zoologist 13: 529-541.

Martir, A. W., F. M. Harrison, M. J. Huston, and D. M. Stewart. 1958. The blood volumes of some representative molluscs. Journa? of Experimential Biology 35: 260-279.

Mattisson, A. G. M. and R. B. Beechey. 1966. Some studies on celJular fractions of the adductor muscle of Pecten maximus. ExperimentaI Cell Research 4I: 227-243.

Moon, T. W. and A. W. Pritchard. 1970. Metabolic adaptations in vertically-separated populations of Mytilus californianus Conrad. Journal of Experimental Marine Biology and Ecology 5: 35-46.

Tappel, A. I. 1960. Cytochromes of muscles of invertebrates. Journal of Cellular and Comparative Physiology 55: 111-126.

Taylor, A. C. 1976a. Burrowing behavior and anaerobiosis in the bivalve Arctica islandica (I.). Journal of the Marine Biological Association of the United Kingdom 56: 95-109.

Taylor, A. C, 1976b. The cardiac responses to shell opening and closure in the bivalve Arctica islandica ( $\left.I_{.}\right)$. Journal of Experimental Biology 64: 751-759.

Taylor, A. C. and A. R. Brand. 1975a. Effects or hypoxia and body size on the oxygen consumption of the bivalve Arctica islandica (L.). Journal of Experimental Marine Biology and Ecology 19: $187-196$.

Taylor: A. C. and A. R. Brand. 1975b. A comparative study of the respiratory responses of the bivalves Arctica islandica (L.) and Mytilus edulis $L$. to declining oxygen tension. Proceedings of the Royal Society of London B 190: $443-456$.

Trueman, E. F. and G. A. Lowe: 1971. The effect of temperature and littoral exposure on the heart rate of a bivalve mollusc, Isognomum alatus, in tropical conditions. Comparative Biochemistry and Physiology 38A: 555-564.

White, K. 1937. Mytilus. Liverpool Marine Biology Committee Memoirs. XXXI. I'he University Press of Liverpool. $117 \mathrm{pp}$.

Wijsman, T. C. M. 1975. pH fluctuations in Mytilus edulis I. in relation to shell movements under aerobic and anaerobic conditions. Pages 139-147 in H. Barnes, ed. Proceedings of the Ninth Europein Marine Biology Symposium. Aberdeen University Press.

Zwaan, A. de and A. M. T. de Bont. 1975. Phosphoenolpyruvate car- 
boxykinase from adductor muscle tissue of the sea mussel Mytilus edulis I.. Journal of Comparative Physiology 96: 85-94.

Zwaan, A. de and T. C. M. Wijsman. 1976. Anaerobic metabolism in Bivalvia (Mollusca). Characteristics of anaerobic metabolism. Comparative Biochemistry and Physiology 54B: 31.3-324.

Zwaan, A. de and D. I. Zandee. 1972. The utilization of glycogen and accumulation of some intermediates during anaerobiosis in Mytilus eduiis L.. Comparative Biochemistry and Physiology 43B: $47-54$. 
VITA

\section{Charles Edward Booth}

Born in Clevelanả, Ohio on January 9, 1952. Graduated from Elyria High School in Elyria, Ohio, June, 1970. Received a B.A. in biology from the College of Wooster, Wooster, Ohio, in June, 1974. Entered graduate school in the Department of Biology at the College of Wilifam and Mary in September, 1974. Served as a graduate teaching assistant in the Department of Biology, 1975-76. Receivea a. Summer Research Assistantship from the University of Texas Marine Science Institute, 1976. Currently a candidate for the degree of Master of Arts in Biology. 